\title{
REGIONAL DEVELOPMENT AND REGIONAL POLICY
}

\author{
Dejan Šabić ${ }^{{ }^{1}}$, Snežana Vujadinović ${ }^{*}$ \\ "University of Belgrade - Faculty of Geography, Belgrade
}

\begin{abstract}
Economic polarization is a process that is present at global, national and regional level. Economic activity is extremely spatially concentrated. Cities and developed regions use the agglomeration effect to attract labor and capital, thus achieving more favorable economic conditions than the agrarian region. Scientific research and European experiences over the past decades have contributed to the discrepancy among theorists about the causes and consequences of regional inequalities. Regional development is a complex process that involves a multidisciplinary approach. Without a detailed analysis of successful regional development cases, the implementation of their development systems directly to other regions can lead to the loss of time, capital, and human resources. Regional development is a process that needs to be adapted to specific conditions. Each region has its own identity and unique characteristics. Key factors of development include: natural and human resources, level of technological development, capital, knowledge, institutional and legislative framework, values, ethics and commitment. Regarding the pace and nature of regional development, institutional structures can play a key role. The prevailing opinion today is that regional development is closely linked to the use of endogenous capacities. The region can achieve long-term progress only if it uses its specific properties and endogenous / internal capacities. The challenge for each region is to use its endogenous resources that will make it competitive and attractive to the market. The progress of one region depends to a large extent on the circumstances and networking of different sectors at the local level. The modern concept of neo-endogenous development implies integral and sustainable development of the region, which includes the harmonization of economic, social and ecological goals. It combines the spatial, temporal and multisectoral dimension and emphasizes «the reciprocal of local and
\end{abstract}

${ }^{1}$ Corresponding author: D. Šabić, University of Belgrade - Faculty of Geography, Studentski trg 3/III, 11,000 Belgrade, Serbia; e-mail: dejansabic@yahoo.com 
external forces in the control of development processes.» Undeveloped, mainly rural regions are no longer just territories that provide food and are not identified exclusively with the agrarian environment. Regional or cohesion policy is an important mechanism for sustainable economic development. Regional policy aims to reduce underdevelopment. The main motive for countries to adopt regional policies is to help poor and backward regions, for whose development and recovery the state itself does not have enough strength. Regional development in a comprehensive way defines regional development priorities and ways of their realization.

Key words: region, regional development, economic polarization, regional policy, modern concept of development.

\section{Introduction}

In the last decade, the interest of geographers, urban planners, demographers, economists, politicians, spatial planners, cultural scientists, sociologists for regional development issues, unequal territorial distribution of income and unequal economic opportunities has been significantly increased. Regional development is under influence of global processes such as the diffusion of high technology innovations, accelerated population growth, the consumption of goods and the deepening of imbalances in the distribution of wealth and available natural and human resources. Economic polarization is a process that is present at global, national and regional level. Economic activity is extremely spatially concentrated. Cities and developed regions use the agglomeration effect to attract labor and capital, thus achieving more favorable economic conditions than the agrarian region. Many relevant authors explain that the globalization is caused by deepening existing interregional and intraregional differences (Scott and Storper, 2003; Crafts, 2004; McCann, 2008; RodriguezPose and Gill, 2006; Brakman and van Marrewijk, 2008). Economic policy often focusses only on macroeconomic conditions and targets such as reducing budget deficits, reducing inflation and liberalizing trade and prices. Economic policies and strategies often ignore regional and local specifics that can represent significant development potential. Ultimately, the national economic and social development itself is a sum of all local achievements. There is an increasing consensus that regional institutions and actors can play a significant role in promoting economic development. They can launch bottom-up initiatives in order to strengthen the regional economy. Among the benefits of policy-making at the regional level compared to central policy-making is the possibility of close coordination between different actors, efficient use of resources, knowledge of regional problems and recognition of a certain regional advantage. Eu- 
Regional Development and Regional Policy

ropean trends reflect the general belief that economic growth, self-sustaining recovery, the quality of public services and the democratic participation of citizens are more effective if authoritative institutions are largely not centralized.

\section{Previous research}

\section{European knowledge and practical experience in improving regional development}

There are a lot of articles in which authors deal with the problems of regional development, regionalization as an instrument of decentralization, factors that influence the concentration, dispersion and migration of the population, as well as the correlation between social capital and regional development. In accordance with classical theories, the concentration of the population on the one hand and its dispersion on the other, are key issues for many researchers in the world (Vining and Kontuly, 1978; Hall and Hay, 1980; Fielding, 1982; Champion, 1989; Borgegard et al., 1995). According to Borgegard et al. (1995), the geographers identified several of the main factors that influence the concentration of the population or its dispersion. These are: demographic (natural growth, demographic structures, social capital, migrations, etc.), economic (employment dynamics, population income, housing costs, state of transport systems, location of physical resources, accessibility to larger settlements), sociopsychological (the need of social groups or individuals to change the place of residence, the attitude of the individual towards different geographical locations, different lifestyles and the environment) and political factors (population or family policy, social protection, local and regional policy, etc.). Scientific research and European experiences over the past decades have contributed to the discrepancy among theorists about the causes and consequences of regional inequalities (Petrakos and Saratis, 2000). In several studies, some authors have attempted to determine how to approach developed and underdeveloped regions in the conditions of a new economic environment (Barro and Sala-i-Martin, 1991; 1992; 1995; Levine and Renelt, 1992, Sala-i-Martin, 1994; 1997; Quah, 1996). Some authors direct their research to the position of the region in relation to the unique economic space of the European Union (Abraham and Van Rompuy, 1995; Armstrong, 1995; Molle and Boeckhout, 1995). In Europe, among theorists, there is an ongoing debate about old and new regional policies (Siegel, 1999; MacLeod, 1999; Keating, 1998), while some authors affirm a new regional policy (Söderbaum and Shaw, 2003; MacLeod, 2001; Mansfield and Milner, 1999). In their works, it implies that there are old regions that have disappeared (historical regions) or are in the process of overcoming. 
According to Frisken (2001), the theory of a new regional policy has evolved over the past several years, and this has been discussed among theorists such as Dodge, 1996; Orfield, 1997; Peirce, Johnson and Hall, 1993; Rusk, 1995; 1999 and Savitch and Vogel, 2000. According to them, a new regional policy aims to address the negative consequences arising from fragmented government structures. They focus on the cooperation of regional authorities that can enable regions to be more competitive in the global economy and to provide financial and other forms of cooperation to poor cities so that they can effectively contribute to the economies of their regions (Frisken, 2001). As Norris (2001) argues, the new regional policy distinguishes between governments. He points out that existing regional institutions can be activated in a new way, through the cooperation of regional authorities and citizens, as well as through horizontally linked organizations (Savitch and Vogel, 2000). According to Frisken (2001), voluntary co-operation between different actors may be a sufficient instrument for achieving regional goals, despite the failure to achieve structural reforms in the past. According to Triglia (2001), Tura and Harmaamkorpi (2005) and Zientara (2008), social capital plays a significant role in the new regional policy. Although there are different opinions (Putnam, 1995; Trigilia, 2001), it is generally accepted that the new concept of a region is based on aspects of social reality (Field, 2003; Pastor et al., 2000, Maskell, 2001). Some studies deal with the emergence of regional inequalities in the countries of Southeastern and Eastern Europe. Some of them relate to various aspects of regional development, in particular through the enlargement of the European Union (Dunford and Smith 2000; Bachtler and Downes 2000; Hamilton 1999; Scott and Storper 2003; Smith 2004). Smith (1998) and Dunford and Smith $(1998,2000)$ noted that regional inequalities began to emerge shortly after the change of political regimes in the former socialist countries.

Most of the countries of Southeastern and Eastern Europe had a challenging path to the European Union (Linnet, 2003; Musil, 2005), with the promise of future prosperity as the leading light at the end of the tunnel, but also with numerous victims on that road. A visible and explicit aspect of transition is reflected in the social-spatial polarization of the countries of Southeastern and Eastern Europe (Boren and Gentile, 2007), which manifests itself through changes in the sectoral composition of employment, as industry and agriculture are facing job losses, while new jobs appear mainly in the service sector, and the rise in unemployment. 
Regional Development and Regional Policy

\section{Results and discussion}

\section{Regional development goals}

Regional development is a complex process that involves a multidisciplinary approach. Without a detailed analysis of successful regional development cases, the implementation of their development systems directly to other regions can lead to the loss of time, capital, and human resources. Regional development is a process that needs to be adapted to specific conditions. Each region has its own identity and unique characteristics. In this respect, there is no entrepreneurial regional policy that can be directly applied to other regions (Todtling and Trippl, 2005). So, regional development is a dynamic process in which we cannot simply make an imitation or a copy of other successful cases of regional development. However, to some extent it is possible to use some successful regional development strategies from one region and apply them to another region that has similar geographical, institutional, organizational and cultural characteristics. Several factors are influenced by regional development, with some factors influencing directly, while others influence indirectly.

Key factors of development include: natural and human resources, level of technological development, capital, knowledge, institutional and legislative framework, values, ethics and commitment. Regarding the pace and nature of regional development, institutional structures can play a key role. In other words, the nature of the relationship between the state and the region, between regional SMEs (small and medium-sized enterprises) and other companies, but also between university or research centers and regional firms, can be the main factor for the positive economic development of the region. Numerous examples from the region around the world corroborate the claim that cooperation between private and public institutions, universities and local industry, between government and local corporations and firms, is important for the prosperity of the region.

The objectives of regional development are to improve the development of endangered (agricultural and industrial) regions, encourage employment (through retraining and combating structural unemployment), encouraging youth employment and more. Therefore, regional programs support the development of entrepreneurial culture, entrepreneurship and local economic development, encouraging different innovations. Citizens, user groups, local and regional authorities are actively involved in the financing process. Funds from regional funds are provided as direct interventions in the economy, and are intended for enterprises, infrastructure development 
and administration. Also, funds for the establishment of small and medium enterprises, industrial and technology parks, so-called "incubators" of business centers, free zones, improved business areas and other mechanisms of sustainable development are approved. In order to determine which region needs assistance, quantitative data are most commonly used. Experience from practice has shown that these indicators are often scarce and unreliable, and should be combined with the analysis of qualitative indicators. So, for example, if the region has a low unemployment rate and does not record emigration, it is defined as a stable and rich region, which does not have to correspond to the real state (Đorđević et al., 2009). In addition, developmental effects in one region can have negative effects for neighboring regions, while market uncertainty makes it difficult to direct the development of vulnerable regions. Therefore, the choice of the most effective instrument for the implementation of regional policies is a major challenge. The involvement of local authorities and regions in this assessment is important because they best recognize local specifics, needs, and constraints.

Sengenberger (1994) distinguishes four main objectives of regional development: endogenous, balanced, sustainable and comprehensive. Endogenous development implies the region's efforts to mobilize as much as possible their own resources in order to achieve the independence and diversity of economic activities. In doing so, this model of development does not prevent external financial support and investments, as well as cooperation with other regions. Achieving balanced development means that various territorial units, i.e. neighboring local governments and regions coordinate their activities with their mutual benefit in order to promote social cohesion. Regional development should be sustainable, i.e. not to jeopardize the needs of future generations. Comprehensive development involves not only quantitative (growth rate, employment), but also qualitative goals (broad participation in decision-making, national and gender equality, preserved environment). Realization of the goals of regional development of a state depends not only on the performance of one region, but also on the functioning of other units, the general socioeconomic development of the state and a larger spatial unit.

\section{Contemporary concept of regional development}

The prevailing opinion today is that regional development is closely linked to the use of endogenous capacities. The region can achieve longterm progress only if it uses its specific properties and endogenous / internal capacities (Scott and Storper, 2003). The challenge for each region is to use its endogenous resources that will make it competitive and attractive to the 
market. The progress of one region depends to a large extent on the circumstances and networking of different sectors at the local level. Entrepreneurial spirit is one of the key factors of regional development (Morrison, 2000). The region can create a comparative advantage by specializing in an industrial branch (Amin, 1999). Regions can use their existing local resources and potentials to present their specific and different products on the global market.

Also, the nature of social interactions between individuals living in a particular region is crucial to the development and progress of the region. This has even greater significance and weight if we take into account that new approaches to regional development do not look at the economy and society in particular. That is, some scientists argue that regional development can not be based solely on economic calculations, that is, pure pragmatic approaches without taking into account the important roles of social capital and citizen associations. The widespread participation of citizens and the spatial proximity of regional entrepreneurs is an important factor for cross-networking, and therefore also for regional development (Asheim, 1985; Amin, 1999). The sense of local identity, trust among local actors, close social relationships, significantly contribute to cooperation and transfer of knowledge and innovation, as well as the exchange of human and material resources between regional enterprises (Biggiero and Sammarra, 2001). A sense of belonging to an individual in a region is often a strong motivating force that contributes to regional progress.

In the official documents of the European Union, the realization of territorial cohesion is directly related to the concept of neo endogenous development. The basic assumption of a neo endogenous approach is in the combination of the influence of exogenous and endogenous development factors (Todling, 2011; Warf and Arias, 2009; Vanclay, 2011). The neo-endogenic development model, as a modern perception of the endogenous model, focuses on the use of local natural and socioeconomic resources, as well as on dynamic interactions between the local level and its wider political, institutional, market and natural environment (Павловић et al., 2016). According to this model, the key to successful local development lies in institution building and the mobilization of internal human resources that need to be adapted to external influences. The main means of achieving this goal is related to the participation of individuals and social groups and local partnerships, as well as the active participation of local stakeholders (local government, entrepreneurs, volunteers) in development processes at local and higher levels (Shucksmith, 2000). According to this model, the function of (economic) development includes more and more factors that were previously regarded as "non-economic" (Petrović and Toković, 2016). 
The modern concept of neo-endogenous development implies integral and sustainable development of the region, which includes the harmonization of economic, social and ecological goals. It combines the spatial, temporal and multisectoral dimension and emphasizes "the reciprocal of local and external forces in the control of development processes." Undeveloped, mainly rural regions are no longer just territories that provide food and are not identified exclusively with the agrarian environment.

Rural environments in developed European countries are increasingly becoming places suitable for the quality of life of the population (unlike the environment that was once abandoned by the departure of able-bodied people in the city). Some peripheral regions take up the function of the place for rest and recreation. In this way, these and other functions are increasingly transforming traditional agricultural regions into spending regions (Јанковић, 2007). Agricultural production in the context of integral development, in addition to the traditional role, also affects the formation of territorial identity (Modern brands). Under these conditions, the economy is diversified and exceeds the boundaries of primary production by linking it with the services sector (Bogdanov, 2007). It is therefore not surprising why modern European rural development strategies emphasize the importance of integral development and cross-sectoral cooperation and coordination. Although agriculture can be a competitive and leading activity in peripheral regions, in most cases the development of complementary activities should be considered (Barkley and Wilson, 1992; Ray, 2000; 2006). Some agricultural regions continue to show successful self-sustaining growth due to the effective valorization of complementary advantages (Galdeano-Gomez et al., 2010; Petrakos and Saratsis, 2000).

\section{Conclusion}

Regional or cohesion policy is an important mechanism for sustainable economic development. Regional policy aims to reduce underdevelopment. The main motive for countries to adopt regional policies is to help poor and underdeveloped regions, for whose development and recovery the state itself does not have enough strength. Regional development in a comprehensive way defines regional development priorities and ways of their realization.

Regional economic performance is increasingly associated with features that are socially and politically created. So, for example, the quality of the environment and social relations, material and non-material infrastructure, access to information and new technologies, the availability of finance 
or the possibility of establishing relationships with international companies are advantages that enhance the competitiveness of companies in the region.

Regional policy according to this bottom-up approach, focuses on neo endogenous growth and mobilizes all the resources of the region, with the possible support of the center. This assumes that funds are better spent on investments in local physical and social infrastructure - i.e. local transport and communications, technical services, education, training and housing, with the aim of encouraging innovation and new technologies and products, and generally improving the quality of work and life in the field.

The duty of each state is to care about the balanced development because it contributes to political and social stability and creates conditions for a more dynamic economic development of all territorial units. The greatest challenge in creating a policy of balanced regional development in transition countries relates to rural environments in which social and economic competences significantly increase poverty. The development of the region is closely connected with the still-living and balanced spatial-functional, socioeconomic and demographic development. Local communities in the regions are gaining importance in their efforts to prevent existing urban-centered tendencies.

In the former socialist countries, balanced regional development has not been seen as an integral part of overall social and economic development. The problems of regional development have been marginalized and analyzed as one separate and not very significant dimension of the overall development of the state. The fact that development has its own regional dimension was constantly avoided, and that the definition of institutional development mechanisms is by no means regionally neutral. Regional differences from the level of development level were observed, so their economic, social and political consequences were neglected. It was mainly aimed at the more dynamic development of the underdeveloped regions, for which funds were allocated and the incentive mechanism was defined. Regional development goals have been defined in a general way and have been repeated for years. The incentive policy, as a sort of development compaction, failed to prevent further lagging behind the underdeveloped regions. Such an approach inevitably led to the deepening of regional and structural development problems in most of the former socialist states and an increase in the so-called " vulnerable regions. Based on indicators of development (population density, migration, per capita income, production volume, growth rate and unemployment, productivity, access to local and state services), four groups of vulnerable regions are most often identified: rural underdevel- 
oped regions with high unemployment; regions with the decadent industry, underdeveloped technology and a slow orientation towards new models of the economy; overcrowded and contaminated regions with high concentrations of production and marginal, neglected regions (Đorđević et al., 2009).

The transition period further deepened the differences in the regional development of the former socialist states. Management of regional development was necessary to be institutionalized, redefine the role of the state in order to promote regional development through the application of new concepts of development policies to eliminate or at least reduce the consequences of transition. Different factors have influenced the level of unemployment, decline in household income, the privatization process and capital investments: attractiveness for investments, network of corridors, border-positioning, technological innovations, production capacities, social opportunities, large investments in a certain location, social disposition for introduction news and progress. Institutional causes of the increase in regional disparities should be sought in the co-ordination of sectoral and regional policies, and on the other hand, by leaving the development of undeveloped free markets without built institutions. This led to the polarization and deepening of their problems, directing economic and social activities and population in developed regions and urban agglomerations, resulting in a population and economic super concentration. The differences are largely the result of regional specifics, in particular the structure of the economy that affects easier or more difficult adjustment to current economic and social changes. The differences have been shown in the order of the taken transitions.

\section{Acknowledgements}

The paper is the result of the research within the project no. 176008 funded by the Ministry of Education and Science of the Republic of Serbia.

\section{References}

Abraham F. and van Rompuy P. (1995). Regional convergence in the European monetary Union. Papers in Regional Science, 74 (2): 125-142.

Amin, A. (1999). An Institutionalist Perspective on Regional Economic Development. International Journal of Urban and Regional Research 23: 365-378.

Armstrong, H. W. (1995). Convergence among regions of the European Union, 1950-1990. Papers in Regional Science 74 (2): 143-152. 
Asheim, B. T. (1985) Capital accumulation, technological development and the spatial division of labor: a framework for analysis, Norwegian Journal of Geography, 45, pp. 87-97.

Bachtler, J. and Downes R. (2000) The Spatial Coverage of Regional Policy in Central and Eastern Europe. European Urban and Regional Studies 7 (2): 159-174.

Barkley, D. L. and P. N. Wilson (1992). Is alternative agriculture a viable rural development strategy? Growth and Change 23 (2): 239-253.

Barro, R. J. and Sala-i-Martin, X. (1991). Convergence across states and regions. Brookings Papers on Economic Activity I: 107-182.

Barro, R. J. and Sala-i-Martin, X. (1992). Convergence. Journal of Political Economy, 100: 223-251.

Barro R. J and Sala-i-Martin X. (1995). Economic Growth. McGraw Hill, New York

Biggiero L. and Sammarra, A. (2001). Identity and Identification in Industrial Districts. Journal of Management and Governance, 5: 61-82.

Boren, T. and Gentile, M. (2007). Metropolitan Processes in Post-Communist States: an Introduction. Geogr. Ann., B 89 (2): 95-110.

Bogdanov, N. (2007). Small rural households in Serbia and the rural economy. Ministry of Agriculture, Forestry and Water Management, Belgrade.

Borgegard, L. E., Hakansson, J. and Malmberg, G. (1995). Population Redistribution in Sweden: Long Term Trends and Contemporary Tendencies, Geografiska Annaler. Series B, Human Geography 77 (1): 31-45.

Brakman, S. and van Marrewijk, C.(2008). It's a big world after all: On the economic impact of location and distance. Cambridge Journals of Regions, Economy and Society 1:411-437.

Champion, A. G. (1989). Conclusion: temporary anomaly, long term trend or transitional phase? In Champion, A. G. (eds.) Conturer urbanization. The Changing Pace and Nature of Population Deconcentration. Edward Arnold, London, 266.

Crafts, N.(2004). Globalization and economic growth: A historical perspective. The World Economy 27 (1): 45-58.

Dodge, W. R. (1996). Regional excellence. Governing together to compete globally and flourish locally. Washington, DC: National League of Cities.

Dunford, M. and Smith, A. (1998). Uneven development in Europe. In D. Pinder (Ed.), The new Europe:economy, society and environment, Wiley, Chichester. 
Dunford, M. and Smith, A. (2000). Catching up or falling behind? Economic performance and regional trajectories in the new Europe. Economic Geography 76 (2): 169-95.

Đorđević, S., Stojanović, S. i Vesić Antić, A. (2009). Pokrenimo zajednice! Priručnik za javno zastupanje u procesu decentralizacije. Balkanski fond za lokalne inicijative (BCIF). 2009 (Beograd: Paragon).

Field, J. (2003). Social capital. Routledge, London.

Fielding, A. J. (1982). Counter urbanization in Western Europe. Progress in Planning 17 (1): 1-52.

Frisken, F. (2001). Regionalism Reconsidered. Journal of Urban Affairs 23 (5): 467-478.

Galdeano-Gomez,E., Aznar-Sanchez, J. and Perez-Mesa, J. (2010). The Complexity of Theories on Rural Development in Europe: An Analysis of the Paradigmatic Case of Almeria (Southeast Spain). Sociologia Ruralis 51 (1): 54-78.

Hall, P. and Hay, D. (1980). Growth centers in the European urban system. Heineman Educational, London.

Hamilton, F. E. I. (1999). Transformation and Space in Central and Eastern Europe. The Geographical Journal 165 (2): 135-144.

Keating, M. (1998). Political economy of regionalism. In: Keating, M., Loughlin, J. (Eds.), 17-41.

Levine, R. and Renelt, D. (1992). A sensitivity analysis of cross - country growth regressions. American Economic Review 82 (4): 942-963.

Linnet, J. (2003). An everyday moral economy: NGO activism among young Latvians, in Arnstberg, K. O. and Boren, T. (Ed.) Everyday Economy in Russia, Poland and Latvia. Södertörn Academic Studies 16, Almqvist \& Wiksell, International, Stockholm, 193-212.

MacLeod, G. (1999) Place, politics and place dependence. European Urban and Regional Studies 6 (3): 231-253.

MacLeod, G. (2001). New Regionalism Reconsidered: Globalization and the Remaking Of Political Economic Space. International Journal of Urban and Regional Research 25 (4): 804-829.

Mansfiield, E. and Milner, H. (1999). The wave of new regionalism. International Organization 53 (3): 589-627. 
Maskell, P. (2001). Social capital, innovation and competitiveness. In S. Baron, J. Field and T. Schuller (eds.), Social capital: critical perspectives, Oxford University Press, Oxford.

McCann, P. (2008). Globalization and economic geography: The world is curved, not flat. Cambridge Journal of Regions, Economy and Society 1:351-370.

Molle, W. and Boeckhout, S. (1995). Economic disparity under conditions of integration - a long term view of the European case. Papers in Regional Science 74 (2): 105-123.

Morrison, A. (2000). Entrepreneurship: What triggers it? International Journal of Entrepreneurship Behavior and Research. 6 (2): 59-71.

Musil, J. (2005). Prague returns to Europe, in Hamilton, F. E. I., Dimitrovska Andrews, K. and Pichler-Milanovic, N. (Ed.): Transformation of Cities in Central and Eastern Europe - towards Globalization. United Nations University Press, Tokyo.

Norris, D. (2001). Prospects for regional governance under the new regionalism: Economic imperatives versus political impediments. Journal of Urban Affairs, 23 (5): 557-571.

Orfield, M. (1997). Metropolitics: A regional agenda for community and stability. Washington, DC: Brookings Institution and Cambridge, MA: The Lincoln Institute of Land Policy.

Pastor, M., Dreier, P. Grigsby E. and Lopez-Garza M. (2000). Regions that work: how cities and suburbs can grow together. University of Minnesota Press, Minneapolis.

Peirce, N., Johnson, C. and Hall, J. S. (1993). City-states: How urban America can prosper in a competitive world. Washington, DC: Seven Locks Press.

Petrakos, G. and Saratsis, Y. (2000). Regional inequalities in Greece, Papers Reg. Sci. 79: 57-74.

Petrović, M. i Toković, M. (2016). Neoendogeni razvoj gradova i ekološki paradoks. Sociologija, 58:181-209.

Putnam, R. D. (1995). Bowling alone: America's declining social capital. Journal of Democracy, 6 (1): 65-78.

Quah, D. T. (1996). Empirics for economic growth and convergence. European Economic Review 40 (6): 1353-1375. 
Ray, C. (2000). Endogenous socioeconomic development in the European Union: issues of evaluation. Journal of Rural Studies, 16(4): 447-458.

Ray, C. (2006), Neo-endogenous rural development in the EU, in: P. Cloke, T. Marsden, and P. Mooney, eds. Handbook of Rural Studies, London/ Thousand Oaks/New Delhi, SAGE, pp. 278-291.

Rodriguez-Pose, A. and Gill, N. (2004). Is there a global link between regional disparities and devolution? Environment and Planning A 36 (12): 2097-2117.

Rusk, D. (1999). Inside game, outside game. Winning strategies for saving urban America. Washington, DC: Brookings Institution Press.

Rusk, D. (1995). Cities without suburbs (2nd Ed.). Washington, DC: The Woodrow Wilson Center Press.

Savitch, H. V. and Vogel, R. K. (2000). Paths to new regionalism. In H. V. Savitch \& R. K. Vogel (Eds.), Symposium on the new regionalism and its policy agenda, State and Local Government Review, 32 (3): 158-168.

Sala-i-Martin X. (1994). Cross-sectional regressions and the empirics of economic growth. European Economic Review 38: 739-747.

Scott, A. J. and Storper, M. (2003). Regions, globalization, development. Regional Studies 37 (6/7): 579-593.

Sengenberger, N. J. (1994). Restructuring at the Global Level: The Role of International Labour Standards, in N. J. Sengenberger and D. Campbell (eds) Creating Economic Opportunities: The Role of Labor Standards in Industrial Restructuring, Geneva: ILO, 395-418.

Shucksmith, M. (2000). Endogenous Development, Social Capital and Social Inclusion: Perspectives from LEADER in the UK. Sociologia Ruralis, 40 (2): 208-218.

Siegel, F. (1999). Is regional government the answer? Urban Illusions (II), The Public Interest 137: 85-98.

Smith, A. (1998). Restructuring the regional economy: industrial transformation and regional development in Slovakia. Edward Elgar, Cheltenham.

Smith, A. (2004). Regions, Spaces of Economic Practice and Diverse Economies in the New Europe. European Urban and Regional Studies, 11 (1): 9-25.

Söderbaum, F. and Shaw, T. (eds.) (2003). Theories of the New Regionalism. Palgrave Macmillan, Houndsmill.

Sykora, L. (1999). Changes in the internal spatial structure of post-communist Prague, Geo-Journal 49 (1): 79-89. 
Todtling, F, and Trippl, M. (2005). One size fits all? Towards a differentiated regional innovation policy approach. Research Policy Amsterdam, 34 (8): 1203-1219.

Todling, F. (2011). Endogenous approaches to local and regional development policy. Pike, A., Rodriguez-Pose, A., Tomaney, J. (eds.). Handbook of Local and Regional Development, Routledge, 333-344.

Trigilia, C. (2001). Social capital and local development. European Journal of Social Theory, 4 (4): 427-442.

Tura, T. and Harmaamkorpi, V. (2005). Social capital in building regional innovative capability. Regional Studies 39 (8): 1111-1125.

Vanclay, F. (2011). Endogenous rural development from a sociological perspective. Stimson, R.. Stouch, R. R., Nijkamp, P. (eds.). New Horizons in Regional Science, Edward Elgar, Cheltenham, UK., Northampton, MA, USA, 59-69.

Vining, D. R. and Kontuly, T. (1978). Population dispersal from major metropolitan regions: An international comparison. International Regional Science Review 3 (1): 49-73.

Warf, B. and Arias, S. (2009). Introduction: the reinsertion of space into the social sciences and humanities, In: Warf, B., Arias, S. (eds.). The Spatial Turn, Interdisciplinary Perspectives, Routledge, 1-10.

Zientara, P. (2008): Polish Regions in the Age of a Knowledge based Economy. International Journal of Urban and Regional Research 32 (1): 60-85.

Јанковић, Д. (2007): Значај социјалног капитала у развоју локалних сеоских заједница. Зборник Матице српске за друитвене науке, 123: 173-190.

Павловић, М., Шабић, Д., Вујадиновић, С. (2015). Теоријске основе истраживања руралног простора. У Павловић, М., Шабић, Д. и Вујадиновић, С. (ур.): Развојни потенцијали и ограничења ревитализације развоја руралног простора Централне Србије, Географски факултет, Београд, 11-31. 